RYSZARD SKRZYNIARZ* - LUBLIN

\title{
BISKUPI A BOŻOGROBCY NA ZIEMIACH POLSKICH W LATACH 1163-1819. ZARYS PROBLEMATYKI
}

Zakon Kanoników Regularnych Stróżów Świętego Grobu Jerozolimskiego powstał podczas pierwszej wyprawy krzyżowej po zdobyciu Jerozolimy 15 lipca 1099 r. Utworzona w dniach 24 i 25 lipca tego roku kapituła kanoników świeckich przyjęła w 1114 r. regułę św. Augustyna i została bezpośrednio podporządkowana patriarsze jerozolimskiemu. Ordo Canonici Regulares Custodes Sanctissimi Sepulchri Hierosolymitani został zatwierdzony w 1122 r. przez papieża Kaliksta II, ponownie w 1128 r. przez papieża Honoriusza II i przez papieża Celestyna II bullą Si mansuetudo z 10 stycznia 1144 roku$^{1}$. Do Polski bożogrobcy zostali sprowadzeni przez Jaksę z Miechowa w 1163 r. i osadzeni w jego dobrach rodowych w Miechowie.

Nowo przybyły na ziemie polskie zakon Kanoników Grobu Bożego szybko uzyskał przychylność hierarchii kościelnej. Już w dyplomie z 1198 r. wystawionym przez Aymara Monachusa, patriarchę Jerozolimy, wśród jego darczyńców spotykamy biskupa krakowskiego Gedkę (1166-1185) i biskupa płockiego Lupusa (ok. 1170 po 1180). Ten pierwszy wyznaczył dziesięciny kościołowi miechowskiemu z czterech osad: Miechowa, Zgorzyc, Komorowa i Goszczy, zaś kościołowi w Skaryszewie dziesięciny ze Skaryszewa i czterech osad: Modrzejowic, Wierzbicy, Odechowa i Krepy².

Nie uniknięto jednak sporów o przekazywane zakonowi dobra. Bożogrobcy otrzymali od biskupa płockiego Lupusa miejscowości Góra i Suchodół. Jego następca zakwestionował tę darowiznę, o czym dowiadujemy się z procesu wyto-

${ }^{*}$ Ryszard Skrzyniarz - dr hab., prof. KUL, kierownik Katedry Biografistyki Pedagogicznej na Wydziale Nauk Społecznych KUL.

${ }^{1}$ S. Nakielski, Miechovia sive promptuarium antiquitatem Monasterii Miechoviensis, Kraków 1634-1646, s. 2-3, podaje $1443 \mathrm{r}$.

${ }^{2}$ Kodeks dyplomatyczny Małopolski (dalej: KDM), wyd. F. Piekosiński, t. 2, Kraków 1886, nr 375, 376; R. Skrzyniarz, Początki archiwum zakonnego bożogrobców w Miechowie, „Archiwa, Biblioteki i Muzea Kościelne”, 71 (1999) s. 407-411; J. Dobosz, Monarchia i możni wobec Kościoła w Polsce do początku XIII wieku, Poznań 2002, s. 415. 
czonego biskupowi płockiemu Gunterowi przez kanoników w 1227 r. Konflikt zakończono ugodą, którą 17 marca 1228 r. nakazał przeprowadzić papież Grzegorz IX, polecając opatowi sieciechowskiemu, Janowi archidiakonowi sandomierskiemu ${ }^{3}$ i prepozytowi św. Michała w Krakowie, aby wdrożyli przyjęty układ między prepozytem miechowskim Michałem a kapitułą płocką w sprawie wsi Góra i Suchodół. Na mocy porozumienia, bożogrobcy zrzekli się spornych miejscowości, a otrzymali z uposażenia diecezji płockiej wieś Krampsko (villas de Crampsco) ze wszystkimi przynależnościami i prawami ${ }^{4}$.

Bożogrobcy pozostawali $\mathrm{w}$ dobrych kontaktach $\mathrm{z}$ biskupem krakowskim Janem Muskatą (1294-1320), gdyż dzielili z nim proczeskie i antyłokietkowe sympatie polityczne, a dobra zakonu, podobnie jak i biskupa, przeżywały najazdy sojuszników Władysława Łokietka oraz jego rekwizycje ${ }^{5}$. Biskup Muskata wraz z Jakubem Świnką (1283-1314), arcybiskupem gnieźnieńskim, w 1302 r. potwierdzili bulle wystawione dla klasztoru miechowskiego przez papieży Innocentego IV i Honoriusza III $^{6}$. Nawet wówczas, gdy dobra miechowskie w czasie wojny domowej ucierpiały z rąk ludzi Muskaty, nie spotykamy bożogrobców wśród procesujących się z biskupem ${ }^{7}$. W Roczniku miechowskim $\mathrm{w} 1317$ r., przy informacji o powrocie Muskaty do diecezji, zanotowano: „Pax magna et moralitas fuit”, co świadczy o tym, że zakon sympatyzował z biskupem - w 1308 r. biskup został wygnany z diecezji przez Władysława Łokietka9 ${ }^{9}$ a w 1311 r. zakonnicy z Miechowa na Spisz.

Zdecydowanie inaczej układały się kontakty bożogrobców z biskupem krakowskim i kardynałem Zbigniewem Oleśnickim (1423-1455). Znany był on z narzucania obranych prepozytów, na przykład norbertankom zwierzynieckim i kanonikom regularnym Bożego Ciała na Kazimierzu. Nie znosił sprzeciwu, a jego wola dawała się we znaki zakonom w diecezji krakowskiej, na przykład więził bezprawnie przez rok opata Mikołaja z klasztoru norbertanów w Brzesku ${ }^{10}$. W przypadku miechowitów nie liczył się z tym, że posiadali oni prawo obsady własnymi zakonnikami prowadzonych przez nich parafii. W czasie rządów Oleśnickiego prepozyt generalny przedstawiał zakonnika wybranego na dany urząd, natomiast biskup dość często mianował, zwłaszcza w parafiach podkrakowskich, duchow-

${ }^{3}$ L. Poniewozik, Prałaci i kanonicy sandomierscy w okresie średniowiecza, Toruń 2004, s. 344345.

${ }^{4}$ Archiwum Główne Akt Dawnych (dalej: AGAD), Dyplomy pergaminowe, nr 6427; KDM, t. 2, nr 391, 392.

${ }^{5}$ T. Pietras, ,Krwawy Wilk z pastoratem”. Biskup krakowski Jan zwany Muskata, Warszawa 2001, s. 150.

${ }^{6}$ Kodeks dyplomatyczny Polski, t. 1, Warszawa 1847, nr 70, 71; Zbiór dokumentów katedry i diecezji krakowskiej (dalej: ZDKDK), wyd. S. Kuraś, t. 1, Lublin 1965, nr 1.

${ }^{7}$ Monumenta Poloniae Vaticana (dalej: MPVat.), wyd. J. Ptaśnik, t. 1, Kraków 1913, nr 121; Pietras, , Krwawy Wilk z pastoratem”, s. 150.

${ }^{8}$ Rocznik Miechowski, „Studia Źródłoznawcze” (dalej: RM), 5 (1960) s. 124 (1317).

${ }^{9}$ Pietras, ,Krwawy Wilk z pastoratem”, s. 132-135.

${ }^{10}$ S. Kuraś, ,, Regestum Ecclesiae Cracoviensis”. Studium nad powstaniem tzw. „Liber Beneficiorum" Jana Dlugosza, Warszawa 1966, s. 38. 
nego diecezjalnego. To doprowadzało do sprzeciwu przełożonego miechowitów i procesów w sądach diecezjalnych, Kurii Rzymskiej, a nawet na soborach. Problem ten zostanie bardziej rozwinięty poniżej.

Czasami dochodziło do otwartych konfliktów między bożogrobcami a biskupami krakowskimi. Taka sytuacja zaistniała 12 grudnia 1539 r., gdy biskup krakowski Piotr Gamrat (1538-1545) najechał Miechów i pod nieobecność prepozyta Tomasza z Olkusza (1508-1542) zdjął go z urzędu oraz skazał na dożywotnie więzienie. Oficjalnym powodem zajazdu było fałszywe oskarżenie prepozyta o kontakty z „heretyczką”, osiemdziesięcioletnią mieszczką krakowską Katarzyną Wajglową, żoną Melchiora. Wiadomym było, że konwent miechowski należał do najbogatszych w Królestwie Polskim, a znany z rozrzutności Gamrat potrzebował pieniędzy. Nakłonił więc Wilamowskiego i Gatkowskiego, aby fałszywie oskarżyli prepozyta Tomasza o kontakty ze skazaną na śmierć i spaloną w $1539 \mathrm{r}$. Katarzyną Wajglową, która nie chciała uznać dogmatu o bóstwie Chrystusa ${ }^{11}$. Dopiero gdy Tomasz wypłacił Gamratowi 2000 złp, a jego sługom 1000 złp, biskup wycofał wszystkie zarzuty wobec prepozyta ${ }^{12}$.

W niektórych przypadkach interwencja biskupa miejsca była konieczna, mimo iż nie miał prawa wizytować klasztorów bożogrobców, znajdujących się na terenie ich diecezji. Powodem takiej wizytacji mogło być duże rozprzężenia w klasztorze. Na przykład w 1490 r. biskup przemyski Jan z Targowiska (15861492) dokonał wizytacji konwentu w Przeworsku, gdyż docierały do niego skargi prepozyta Grzegorza i zakonników. „Chcąc ukrócić wybryki, zreformować błędy i zapobiec zgorszeniu", wydał - mimo iż nie był uprawniony do mieszania się w wewnętrzne sprawy zakonu - wiele zarządzeń: prepozytowi nakazał lepiej żywić braci, dać im chłopca do posług, urządzić izbę chorych; zakonnicy zaś nie mogli samowolnie wychodzić z klasztoru, przebywać w mieście dłużej niż do północy, wszyscy mieli odprawiać przepisane modlitwy, a co tydzień winny odbywać się zebrania kształceniowe, zakazana była również prywatna własność ${ }^{13}$.

Kanonicy Grobu Bożego cieszyli się opieką i dużą przychylnością arcybiskupa gnieźnieńskiego Mikołaja Trąby (1412-1422). Ufundował on i przekazał im kościół w Łęgonicach, należących do dóbr arcybiskupów gnieźnieńskich, a także prawdopodobnie szpital w Kole. Wydaje się, że arcybiskup Trąba nie tylko otaczał troską bożogrobców miechowskich, nadając im nowe placówki, ale również wspierał rozwój ich głównego święta, przypadającego na 15 lipca $^{14}$. Widać to m.in. po wezwaniu fundowanego przez niego kościoła łęgonickiego (Rozesłania Apostołów) i ustanowieniu święta narodowego w rocznicę wiktorii Jagiełły pod Grunwaldem, przypadającą na ten właśnie dzień.

${ }^{11}$ J. Tazbir, Tradycje tolerancji religijnej w Polsce, Warszawa 1980, s. 28.

12 „Archiwum do Dziejów Literatury i Oświaty w Polsce”, 11 (1910) nr 150; Z. Pęckowski, Miechów. Studia z dziejów miasta i ziemi miechowskiej do roku 1914, Kraków 1967, s. 319, przypis pod tekstem.

${ }^{13}$ Nakielski, Miechovia, s. 556-557.

${ }^{14}$ Święto Rozesłania Apostołów było uroczyście obchodzone w związku z kilkoma rocznicami przypadającymi na dzień 15 lipca: zdobycie Jerozolimy, konsekracja bazyliki Grobu Bożego w Jerozolimie, konsekracja kościoła miechowskiego i wiktoria Władysława Jagiełły nad Krzyżakami pod Grunwaldem. 
Nieco inaczej wyobrażali sobie współpracę z zakonnikami następcy arcybiskupa Trąby. W drugiej połowie XV stulecia dochodziło do ingerencji arcybiskupów gnieźnieńskich w wewnętrzne sprawy prepozytury szpitalnej w Gnieźnie, spowodowanych próbami podporządkowania wspomnianej placówki jurysdykcji arcybiskupów. W 1456 r., na synodzie gnieźnieńskim prepozyt Jan, pod cenzurami kościelnymi został zobowiązany do świadczeń materialnych, jako zadośćuczynienie za obrazę arcybiskupa Jana Sprowskiego (1453-1464) i kanonika katedralnego Sędziwoja. Prepozyt okazał skruchę i wyraził zgodę na wizytację konwentu, której przedtem był przeciwny ${ }^{15}$. Jak wiemy, arcybiskup naruszył tym samym przywilej papieski z 1262 r., mówiący o wyjęciu wszystkich domów i żyjących w nich zakonników spod jurysdykcji arcybiskupów i biskupów ${ }^{16}$.

Kontakty między bożogrobcami a arcybiskupami pozostawały w dalszym ciągu napięte. Jednak sami bożogrobcy nie byli bez winy, w 1478 r. arcybiskup Jakub z Sienna (1474-1480) wezwał Stanisława Lutomierskiego, prepozyta gnieźnieńskiego (1458-1486), nakazując mu stosować się do przepisów fundacji. Okazało się, że kanonicy przeznaczali na własne potrzeby dochody z dóbr szpitalnych. Arcybiskup przypomniał wówczas prepozytowi o obowiązkach, ciążących na nim i jego następcach, wynikających z zapisów fundacyjnych ${ }^{17}$. Działając z upoważnienia arcybiskupa, kapituła gnieźnieńska wydała wyrok, w którym zobowiązała prepozyta, aby każdego dnia na śniadanie i obiad zapraszał do swojego stołu czterech duchownych diecezjalnych i sześciu biednych scholarów. Ponadto pod groźbą kar kościelnych i odebrania dóbr szpitalnych w wyroku tym nakazywano prepozytowi odbudować szpital - zapewne był w opłakanym stanie - do dnia św. Wojciecha w następnym roku. Prepozyt nie zgadzał się na taki wyrok kapituły, powołując się na bulle papieża Urbana IV, potwierdzające przywileje Przemysła I i Bolesława Pobożnego oraz arcybiskupa Pełki sprzed 1257 r., w których rzekomo otrzymali oni dobra szpitalne na własny użytek. Mimo wezwań kapituły prepozyt nie przedstawił wspomnianych dokumentów, twierdząc, że zaginęły, natomiast kapituła dysponowała oryginalnym dokumentem z 1243 r., na podstawie którego wydała wyrok. Prepozyt Stanisław Lutomierski odmówił wykonania wyroku, za co w 1479 r. został skazany za nieposłuszeństwo wobec arcybiskupa na trzy grzywny kary ${ }^{18}$. Spór toczył się do 1487 r., kiedy prepozyt zrezygnował z urzędu, jego ustąpienie przyjął arcybiskup Zbigniew Oleśnicki. Po odejściu prepozyta spory o prawidłowe funkcjonowanie szpitala nie ustały. W 1512 r. pożar zniszczył szpital, jednak bożogrobcy nie spieszyli się z jego odbudową.

W konflikt z arcybiskupem Mikołajem Dzierzgowskim (1545-1559) popadł prepozyt Marcin z Wrześni (1537-1554), który prowadząc gorszący tryb życia,

${ }^{15}$ F. Sikora F., Najstarsze dokumenty i dzieje klasztoru bożogrobców w Gnieźnie, „Studia Źródłoznawcze”, 19 (1974) s. 52-53.

${ }^{16}$ Bullarium Poloniae (dalej: BP), t. 1, wyd. J. Sułkowska-Kuraś, S. Kuraś, Romae 1982, nr 731.

${ }^{17}$ Nakielski, Miechovia, s. 537-538; B. Ulanowski, Acta capitulorum saeculi XVI selecta, t. 1, Cracoviae 1894, nr 2168.

${ }^{18}$ Acta capitulorum nec non iudicorum ecclesiasticorum selecta, wyd. B. Ulanowski, t. 1-3, Kraków 1894-1908, nr 2199; Sikora, Najstarsze dokumenty i dzieje klasztoru bożogrobców, s. 53. 
roztrwonił majątek szpitala, za co został usunięty z urzędu w 1554 r. Prepozyt generalny Jan z Lwówka zajął się tą sprawą i w liście do arcybiskupa informował, że Marcinowi został wytoczony proces między innymi za zniszczenia dóbr szpitalnych ${ }^{19}$.

Wydaje się, że nieco lepiej układały się kontakty między prepozytami gnieźnieńskimi a miejscowym arcybiskupem za czasów prepozyta Stanisława z Łowicza (1555-1574), który unikał konfrontacji z władzą archidiecezjalną. Jednak arcybiskup Jakub Uchański (1562-1581) wystarał się u króla Zygmunta Augusta o zgodę na zburzenie szpitala, zaś przeznaczenie jego dóbr na budowę seminarium. Stanisław usilnie zabiegał u króla o cofnięcie tej decyzji. Udało mu się to i w 1570 r. król unieważnił zgodę wydaną już arcybiskupowi Uchańskiemu ${ }^{20}$. Konflikty te były powodowane z jednej strony próbami podporządkowania bożogrobców jurysdykcji arcybiskupa, zaś z drugiej niegospodarnością i chęcią korzystania z dóbr należących do uposażenia szpitala przez przełożonych w Gnieźnie.

Zakusy na bogaty konwent miechowski, ,zaostrzył apetyt” biskupów biedniejszych diecezji. Nawet biskupi diecezji ruskich, dla powiększenia swoich dochodów, zaczęli starania o inkorporowanie bogatszych klasztorów (m.in. benedyktynów tynieckich, cystersów sulejowskich), przede wszystkim jednego z najbogatszych klasztorów Korony, jakim był Miechów ${ }^{21}$. Kanonicy miechowscy, aby zapobiec takim działaniom, wystosowali pismo do papieża Leona X, który w bulli z 1513 r. potwierdził, że klasztor miechowski nie może podlegać żadnej aneksji, a wszelkie tego rodzaju akty prawne będą nieważne ${ }^{22}$. Biskup przemyski Piotr Tomicki (1514-1520), nie zważając na bullę papieską, w dalszym ciągu czynił starania na dworze królewskim i w Rzymie, aby klasztor miechowski został włączony do diecezji przemyskiej. Pokusa sięgnięcia po dochody konwentu miechowskiego ogromna, ostatecznie w 1517 r. biskup uzyskał przychylną decyzję króla Zygmunta I Starego i papieża Leona $\mathrm{X}^{23}$. Bożogrobcy jednak nie dali za wygraną i sprawa przeciągnęła się na lata $1517-1525$, a szala zwycięstwa przechylała się raz na rzecz klasztoru, innym razem na korzyść biskupa przemyskiego. W konflikt ten zaangażowani byli: papież, król Polski, wysocy dostojnicy i dygnitarze królewscy oraz pięć kolejnych sejmów. Obie strony miały swoich zwolenników i przeciwników, a co za tym idzie, musiały wydawać duże sumy pieniędzy na przychylność Stolicy Apostolskiej, dworu królewskiego czy wpływowych ludzi. Łącznie konwent w ciągu dziewięciu lat wydał na ten cel 5660 złp (flore-

\footnotetext{
${ }^{19}$ Nakielski, Miechovia, s. 660-661.

${ }^{20}$ Matricularum Regni Poloniae summaria, wyd. T. Wierzbowski, t. 5, cz. 1, Warszawa 1919, nr 4291; Sikora, Najstarsze dokumenty, s. 54.

${ }^{21}$ Dochód klasztoru miechowskiego ustalony dla poboru dziesięciny papieskiej w latach 13251327 wynosił 300 grzywien. Był on na równi z klaryskami sądeckimi i należał do najwyższych w diecezji krakowskiej. Dla przykładu benedyktyni łysogórscy i cystersi jędrzejowscy mieli ustalony dochód na 100 grzywien. Zob. Pęckowski, Miechów, s. 376, przyp..

${ }^{22}$ Nakielski, Miechovia, s. 590.

${ }^{23}$ Archiwum Parafialne w Miechowie, Dispositio privilegiorum Conventus Miechoviensis, brak sygn., scat. II.
} 
nów $)^{24}$. Leon X w 1520 r. w trzech bullach zatwierdził wszystkie dotychczasowe przywileje, immunitety i wyłączenia nabyte na mocy dotychczasowych przywilejów papieskich, królewskich i książęcych. Jednak tego samego lub następnego roku zmienił zdanie i przychylił się do żądań biskupa Tomickiego, wydając dekret inkorporujący konwent miechowski do diecezji przemyskiej. Z powodu braku źródeł trudno powiedzieć, jakich zabiegów dokonali bożogrobcy miechowscy, aby cofnąć dekret Leona X, ostatecznie został on unieważniony w 1522 r. przez papieży Adriana VI oraz Klemensa VII w 1524 roku $^{25}$. Mimo sprzeciwów biskupa przemyskiego Andrzeja Krzyckiego, również król Zygmunt I Stary, dokumentem z 21 grudnia 1525 r., zniósł przyłączenie prepozytury miechowskiej do diecezji przemyskiej, argumentując to tym, iż inkorporacja byłaby sprzeczna z intencją fundatoró $\mathrm{w}^{26}$.

Jednak na plan pierwszy wysuwały się ciągle narastające problemy z duchowieństwem diecezjalnym. Księża ci domagali się płacenia dziesięcin i prawa patronatu w kościołach prowadzonych przez bożogrobców, a to wiodło do konfliktów. Ze względu na to, że miechowici nie mogli prowadzić działalności duszpasterskiej, wystąpili ze skargą na ten stan rzeczy do papieża Urbana IV, który 4 listopada 1262 r. wydał bullę, zatwierdzającą wyłączenie zgromadzenia miechowskiego i wszystkich jego placówek w sprawach duchownych i świeckich spod jurysdykcji arcybiskupów, biskupów, duchowieństwa diecezjalnego i zakonnego, z wyjątkiem patriarchy jerozolimskiego. Zabronił także nakładania klątw i interdyktów na zakonników. W sprawach patronatu nakazał, aby kościoły, w których prawo służyło zakonowi, były rządzone i obsługiwane przez bożogrobców, nawet jeśli dotychczas były prowadzone przez kapłanów diecezjalnych ${ }^{27}$. Papież Urban IV tym rozporządzeniem zdecydowanie podkreślił egzempcję, samodzielność i niezależność w rządzeniu się bożogrobców. Decyzja papieża wcale nie oznaczała, że kanonicy mogli kierować się swoimi prawami w sprawowaniu opieki duszpasterskiej. W prowadzeniu duszpasterstwa podlegali oni biskupowi, na terenie którego placówki te znajdowały się.

Rywalizacja duchowieństwa diecezjalnego z zakonem o obsadę parafii miejskich i wiejskich była powodem wielu procesów toczących się przed sądami kościelnymi. Na przykład, w 1505 r. doszło do konfliktu między kanonikami a duchowieństwem diecezjalnym w sprawie parafii miejskiej w Wyszogrodzie. Jan Popielski nieprawnie zagarnął prepozyturę wyszogrodzką, nie pozwalając przejąć ją Wojciechowi prezentowanemu na ten urząd przez prepozyta Marcina z Radomia (1501-1508) i konwent miechowski ${ }^{28}$.

Znane są również przypadki, gdy księża diecezjalni próbowali objąć nawet te parafie, które miały już wcześniej obsadę zakonną. Biskupi, korzystając ze swych

${ }^{24}$ Nakielski, Miechovia, s. 593.

${ }^{25}$ Tamże, s. 604-606.

${ }^{26}$ Biblioteka Czartoryskich w Krakowie (dalej: BCzK), Dokumenty pergaminowe, nr 753 vol. VIII/43.

${ }^{27}$ AGAD, nr 2346; KDM, t. 2, nr.: 460, 461, 468, 469; BP, t. 1, nr.: 720, 721, 731; Nakielski, Miechovia, s. 183, 184, 187, 189.

${ }^{28}$ AGAD, nr 2673; Nakielski, Miechovia, s. 574. 
uprawnień, nie zatwierdzali kandydata prezentowanego przez konwent miechowski, ale własnego. Tak było w przypadku Jana Pniowskiego, kanonika krakowskiego i profesora Akademii Krakowskiej, który w wyniku życzliwości biskupa krakowskiego Zbigniewa Oleśnickiego, został przed 1438 r. plebanem w Chodowie - parafii należącej do bożogrobców ${ }^{29}$. Pniowski został usunięty z parafii w Chodowie przez Jana, prepozyta miechowskiego, i Jakuba z Krakowa, prepozyta św. Jadwigi w Krakowie (1431-1457). W odpowiedzi Zbigniew Oleśnicki 30 maja 1438 r. polecił Dziersławowi z Borzymowa, archidiakonowi krakowskiemu, i Janowi Elgotowi, kanonikowi i oficjałowi krakowskiemu, przywrócić go w posiadanie parafii w Chodowie, skąd ,nieprawnie” został usunięty przez wyżej wymienionych przełożonych zakonu bożogrobców ${ }^{30}$. Spory między bożogrobcami a kandydatem na plebana nie należącym do kanoników trwały zazwyczaj kilka lat $\mathrm{i}$ były rozstrzygane $\mathrm{w}$ procesach kanonicznych przed sądami biskupimi, a nawet przez papieża lub sobór powszechny. Na przykład, spór bożogrobcy Eliasza z Piotrem, synem Tomasza z Szadka, o parafię w Uniejowie toczył się w latach 1402-1413, a rozstrzygał go sam papież i sędziowie papiescy ${ }^{31}$. Zatarg zakonników o stanowisko plebana w Chodowie ze wspomnianym Janem Pniowskim toczył się w latach 1438-1440, najpierw był rozstrzygany przed sędziami delegowanymi przez biskupa Zbigniewa Oleśnickiego, a później papieżem i Soborem w Bazylei - ostatecznie została przyznana Stefanowi z Trzcińca, krewnemu Jana Pniewskiego $^{32}$. Spór bożogrobców z Mikołajem ze Strojnowa o parafię w Chełmie nad Rabą, toczący się w latach 1452-1459, rozpatrywany był przez sędziów biskupich i oficjała oraz audytorów papieskich ${ }^{33}$. Konflikty takie trwały dość długo, bo jeszcze w $1480 \mathrm{r}$. toczył się proces przed sądem ziemskim krakowskim prepozyta miechowskiego z plebanem chełmskim Mikołajem, który to proces przegrał ten drugi, gdyż po prostu się na nim nie pojawi ${ }^{34}$. W 1482 r. Jakub z Bokszyc, wikariusz i oficjał arcybiskupa gnieźnieńskiego, nakazał duchowieństwu wezwać Stanisława ze Świeradzia, prepozyta kieleckiego i oficjała krakowskiego, aby ten złożył mu dokumenty dotyczące sprawy toczącej się między Janem, prepozytem miechowskim, a Mikołajem, plebanem z Chełma, które posiadał ${ }^{35}$. Jak wynika ze źródeł, leżące w pobliżu Krakowa placówki bożogrobców co jakiś czas miały plebanów narzucanych przez biskupów krakowskich, którzy nie byli członkami zakonu bożogrobców. Prawo prezenty na stanowisko plebana przez konwenty miechowski i krakowski naruszył biskup Zbigniew Oleśnicki, który nie liczył się z uzyskanymi przez bożogrobców przywilejami dotyczącymi obsady placówek zakonnych, mianując swoich ludzi.

Czasami sprawy przybierały zaskakujący obrót - jak podczas sporu bożo-

${ }^{29}$ ZDKDK, t. 2, nr 377; M. Kowalczykówna, Jan Pniowski, PSB, t. 27, s. 1.

${ }^{30}$ BCzart., 428, vol. VIII/46; ZDKDK, t. 2, nr 377, 378.

${ }^{31}$ L. Skórska-Florentin, Les chanoines du Sainte Sépulcre de Miechów. Recueil des actas de 1198-1428, t. 1-6, [b.m.] 1976, t. 4, nr 393, 396; t. 5, nr 413, 416, 438.

${ }^{32}$ AGAD, nr 2313, 2540; BCzart., 448; ZDKDK, t. 2, nr 377, 378, 413.

${ }^{33}$ AGAD, nr 2577, 2584, 2592, 2595.

${ }^{34}$ AGAD, nr 2635.

${ }^{35}$ AGAD, nr 2641. 
grobców z Mikołajem ze Strojnowa o obsadę parafii w Chełmie nad Rabą. Chłopi ze wsi należących do parafii: Chełm, Kłaj i Targowiska pobili Mikołaja, zastępującego komendarza Klemensa z Białej. Sprawa nabrała nieprzyjemnego obrotu, gdyż rozeszła się pogłoska o śmierci Klemensa, a za zaistniałą sytuację obwiniono prepozyta miechowskiego. Na prośbę prepozyta generalnego Jana Oczko (1432-1452), Jan ze Lgoty, scholastyk krakowski, wikariusz generalny biskupa Zbigniewa kardynała Oleśnickiego, zaświadczył, że stanął przed nim komendarz Klemens z Białej, oczyszczając prepozyta miechowskiego tym samym z zarzutów ${ }^{36}$.

Rywalizacja między bożogrobcami a duchowieństwem diecezjalnym o obsadę parafii wiejskich stanowiła zarzewie konfliktów przez cały interesujący nas okres. Duchowieństwo diecezjalne żądało od bożogrobców płacenia dziesięcin, domagało się prawa patronatu w kościołach parafialnych prowadzonych przez zakon, obciążało zakonników daninami, podatkami i innymi świadczeniami. Wydaje się, że wszystko to odbywało się za cichym przyzwoleniem biskupów. Zdarzały się również przypadki kwestionowania najstarszych nadań na rzecz konwentu miechowskiego. Tak było w przypadku kleryka Zdzisława ze Słomnik i jego brata, którzy w 1287 r. toczyli spór o wieś Replice [Rzeplice] ${ }^{37}$, będącą wśród pierwotnych nadań dla klasztoru; wieś tę przysądzono bożogrobcom ${ }^{38}$.

Dochodziło również do konfliktów między szpitalami prowadzonymi przez bożogrobców a parafią, na terenie której one się znajdowały. Tak było w przypadku Raciborza, gdzie tamtejszy szpital św. Krzyża był ściśle związany z parafią św. Piotra i Pawła. Bożogrobcy nie mogli udzielać sakramentów, przebywającym tam chorym, gdyż były one zastrzeżone dla plebana z kościoła parafialnego. Również otwarcie szkoły prowadzonej przy szpitalu doprowadziło do konfliktu między plebanem a zakonnikami, ostatecznie kanonicy zostali zmuszeni do zaniechania jej prowadzenia ${ }^{39}$.

Różnie układały się kontakty konwentu miechowskiego z kapitułą katedralną na Wawelu. W 1327 r. klasztor miechowski ufundował prebendę dla Jana Bródki, jednego z 14 kanoników gracjalnych kapituły katedralnej krakowskiej ${ }^{40}$. Na początku XVI w. doszło do zatargu między prepozytem Tomaszem z Olkusza (15081542) a kapitułą katedralną w Krakowie, w wyniku którego ta ostatnia rzuciła ekskomunikę na prepozyta i cały konwent. W kwietniu 1514 r. sprawa sporu i rzuconej ekskomuniki została rozstrzygnięta w Budzie przez Tomasza kardynała

\footnotetext{
${ }^{36}$ AGAD, nr 2577, 2584, 2592.

${ }^{37}$ Wieś „Replicz”, występująca w dokumencie Monachusa, opustoszała w późniejszym czasie, a w pierwszej połowie XIV w. i później J. Długosz, nie wymieniali jej wśród dóbr klasztornych.

${ }^{38}$ KDM, t. 2, nr 506; Nakielski, Miechovia, s. 286.

${ }^{39}$ Schlesisches Urkundenbuch, t. 6, wyd. H. Applet, W. Irgang, Wien 1998, nr 268; N. Mika, Bożogrobcy raciborscy w średniowieczu, w Klasztor w mieście średniowiecznym i nowożytnym, red. M. Derwich, A. Pobóg-Lenartowicz, Wrocław-Opole 2000, s. 422.

${ }^{40}$ MPVat., t. 1, nr 139, s. 110-111; M.D. Kowalski, Prałaci i kanonicy krakowskiej kapituly katedralnej od pontyfikatu biskupa Nankera do śmierci biskupa Zawiszy z Kurozwęk (1320-1382), Kraków 1996, s. 50.
} 
i patriarchę Konstantynopola, legata na Polskę, Węgry, Ruśs ${ }^{41}$, a 27 czerwca 1514 r. Jan, opat cystersów w Mogile, i Marcin z Olkusza, magister sztuk, kantor kolegiaty św. Floriana na Kleparzu, jako sędziowie, uwolnili prepozyta i braci konwentu miechowskiego od ekskomuniki ${ }^{42}$.

Na podstawie opisanych historii wydawać by się mogło, że bożogrobcy często popadali w konflikty z hierarchią kościelną i duchowieństwem diecezjalnym. Niestety, źródła bardzo rzadko odnotowują pozytywne relacje między duchownymi, choć tych zapewne było zdecydowanie więcej. Przyjrzyjmy się zatem źródłom.

W 1403 r. bożogrobcy otrzymali od Michała Treski (1410-1429), dominikanina, późniejszego biskupa kijowskiego szpital wraz z kaplicą-oratorium w Żarnowcu oraz cztery łany w jego okolicach ${ }^{43}$. Michał Treska, już jako biskup kijowski, stale otaczał swoją fundację opieką̨ ${ }^{44}$ a w $1426 \mathrm{r}$. założył bractwo ${ }^{45}$. Możemy przypuszczać, iż bożogrobcy pozostawali w dobrych kontaktach z arcybiskupem gnieźnieńskim Mikołajem Trąbą, który w 1411 r. powierzył im patronat nad kościołem parafialnym w Łegonicach ${ }^{46}$. Również w innych przypadkach dostrzegamy dobre kontakty kanoników Grobu Bożego z biskupami. W sierpniu 1409 r., po zakończeniu soboru w Pizie, dwaj bożogrobcy towarzyszyli biskupowi krakowskiemu Piotrowi Wyszowi z Radolina (1392-1412) i opatowi tynieckiemu Mścisławowi (1386-1410) w pielgrzymce przez Rzym i Wenecję do Ziemi Świętej, Grobu Świętego w Jerozolimie i miejsca narodzenia Jezusa ${ }^{47}$. W innym zaś przypadku, w 1450 r., Jan Elgot ( $\uparrow 1452$ ), udając się na pielgrzymkę z Janem Długoszem (1415-1480), zaprosił Mikołaja, prepozyta z Przeworska ${ }^{48}$, aby ten mógł im służyć doświadczeniem w czasie podróży do Jerozolimy, gdyż już wcześniej przebywał w Ziemi Świętej ${ }^{49}$.

Nie znamy genezy uprawnień prepozytów gnieźnieńskich, którzy twierdzili,

${ }^{41}$ Pergaminy Archiwum Kapituly Katedralnej Sandomierskiej, oprac. F. Kiryk, Sandomierz 2002 , nr 385.

${ }^{42}$ Tamże, nr 111.

${ }^{43}$ RM, s. 131; Zbiór dokumentów małopolskich (dalej: ZDM), wyd. S. Kuraś, I. SułkowskaKuraś, t. 6, Wrocław 1974, nr 1664; Monumenta Poloniae Historica (dalej: MPH), t. 2 , Lwów 1872, nr 892; J. Wiśniewski, Historyczny opis kościoła, miasta, zabytków i pamiątek w Olkuskiem, Mariówka 1935, s. 505-508.

${ }^{44} \mathrm{KDM}$, t. 4, nr 1206, 1231, 1241.

${ }^{45}$ Wiśniewski, Historyczny opis kościoła, miasta, zabytków i pamiątek w Olkuskiem, s. 500501, 512-514; M. Koczerska, Zbigniew Oleśnicki i Kościół krakowski w czasach jego pontyfikatu (1423-1455), Warszawa 2004, nr 11a, s. 319.

${ }^{46}$ J. Laski, Liber beneficiorum, t. 2, Gniezno 1881, s. 312-313.

${ }^{47}$ RM, s. 1409; Nakielski, Miechovia, s. 382; P. Sczaniecki, Katalog opatów tynieckich, „Nasza Przeszłość", 49 (1978) s. 82.

${ }^{48}$ Prepozytem w Przeworsku od 1448 r. był Mikołaj i to właśnie wtedy poznał go Jan Elgot, który rozsądzał spór o dziesięciny między biskupem przemyskim a sołtysami z okolic Jarosławia i Przemyśla. Prepozyt Mikołaj występował w tym sporze jako prokurator sołtysów. Nakielski, Miechovia, s. 484-487; M. Starnawska, Między Jerozolima a Łukowem. Zakony Krzyżowe na ziemiach polskich w średniowieczu, Warszawa 1999, s. 165-166, przyp. 76.

${ }^{49}$ Codicis epistolaris saeculi decimi qiunti pars posteriora ab anno 1444 ad annum 1492, wyd. A. Sokołowski, J. Szujski, Kraków 1876, n r 95, s. 99-101 - list z 1450 r. 
że od połowy XIV w. piastowali kanonię gnieźnieńską ${ }^{50}$, możemy jednak przypuszczać, że otrzymali ją ze względu na zasługi dla lokalnego kościoła. Zatem wydaje się, że poza wymienionymi incydentami, współpraca bożogrobców z hierarchią i duchowieństwem diecezjalnym układała się poprawnie.

Możemy także przypuszczać, iż prepozyci miechowscy oraz przeworscy, a przede wszystkim prepozyci konwentu św. Jadwigi ze Stradomia i szpitala w Gnieźnie brali udział w ingresach i pogrzebach biskupów krakowskich i przemyskich oraz arcybiskupów gnieźnieńskich, uczestnicząc tym samym w życiu diecezji, na terenie której znajdowały się wymienione konwenty.

Niekorzystny czas dla konwentu miechowskiego nastał w 1567 r., gdy narzucono klasztorowi komendatariuszy. Wśród nich byli przede wszystkim biskupi biedniejszych diecezji: chełmińskiej, chełmskiej, kamienieckiej, łuckiej, płockiej, przemyskiej, warmińskiej i archidiecezji lwowskiej. Pierwszym komendatariuszem był Szymon Ługowski (1567-1583), człowiek niegodziwy i niemoralny; za budzącą zgorszenie chciwość był upominany przez biskupa krakowskiego Piotra

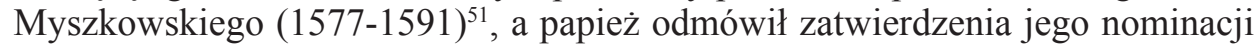
na biskupstwo przemyskie, którego przez dwa lata był nominatem. Po śmierci Ługowskiego biskup Myszkowski radził konwentowi, aby ten przychylił się do woli Stefana Batorego i obsadził na stanowisku prepozyta bratanka królewskiego Andrzeja Batorego (1583-1599). Biskup Myszkowski podkreślał, że przeciwstawienie się woli króla będzie daremne, a może pociągnąć za sobą przykre konsekwencje dla klasztoru miechowskiego, jak to było w przypadku klasztoru cystersów w Sulejowie. Myszkowski przyspieszył termin kapituły wyborczej, nie zważając na to, że niektórzy przedstawiciele konwentów i parafii mogą nie przybyć na czas do Miechowa. Andrzej Batory w 1583 r. został więc prepozytem komendatoryjnym, a już 25 lipca 1584 r. koadiutorem biskupa diecezji warmińskiej Marcina Kromera, w 1593 r. biskupem tejże diecezji, będąc zarazem prepozytem miechowskim. 4 lipca 1584 r. papież Grzegorz XIII nadał kapelusz kardynalski Andrzejowi Batoremu ${ }^{52}$. Kardynał Batory troszczył się o zakon i konwent miechowski, podzielił zakon na prowincje i administrował nim według rad kardynała Karola Boromeusza, a także przeprowadził reformy, mające na celu wzmocnienie rozluźnionej dyscypliny zakonnej, i popierał wyższe wykształcenie zakonników, kupując w tym celu dom w Rzymie ${ }^{53}$.

Wybitnym prepozytem generalnym, a zarazem biskupem, był Maciej Łubieński (1617-1627). Po objęciu prepozytury przystąpił do wizytacji placówek metro-

\footnotetext{
${ }^{50}$ Kodeks dyplomatyczny Wielkopolski, t. 2, Poznań 1878, nr 1459; tamże, t. 7, Poznań 1985, nr 549.

${ }^{51}$ Nakielski, Miechovia, s. 719-720; MPVat., Appendix 1, t. 5, s. 627; R. Skrzyniarz, Eugowski Szymon, EK, t. 11, Lublin 2006, kol. 605-606.

${ }^{52}$ Archiwum Watykańskie, Sekretariat Brewiów, vol. 103, ff. 484-493.

${ }^{53}$ Nakielski, Miechovia, s. 790. Postać kardynała Batorego zasługuje na oddzielne opracowanie ze względu na jego zasługi dla konwentu miechowskiego. T. Glemma, Batory Andrzej, PSB, t. 1, Kraków 1935, s. 351-353; Pęckowski, Miechów, s. 323-328; W. Müller, Batory Andrzej, EK, t. 2, Lublin 1976, kol. 100; M. Majcherek, Materiaty źródtowe zakonu bożogrobców w archiwach watykańskich, w: Bożogrobcy w Polsce, Miechów-Warszawa 1999, s. 159-161.
} 
polii miechowskiej, do reformy administracji, reguły zakonnej i przywrócenia karności. Odbył dwie kapituły generalne w latach 1621 i 1625, dawał dobry przykład zakonnikom, wiele uwagi poświęcał nowicjatowi, popierał studia zakonników w Krakowie i Rzymie, a także urządził i rozszerzył bibliotekę. Mimo objęcia w końcu 1621 r. diecezji chełmskiej, ciągle troszczył się o dobro zakonu. W 1625 r. wraz z bratem Stanisławem, biskupem łuckim, przekazał bożogrobcom patronat ufundowanego i uposażonego przez nich kościoła parafialnego w Wagłczewie ${ }^{54}$. Po objęciu biskupstwa poznańskiego w 1626 r. zrezygnował w 1627 r. z prepozytury miechowskiej. Łubieński był fundatorem murowanego kościoła szpitalnego w Miechowie pw. św. Barbary. Jako biskup poznański, później arcybiskup gnieźnieński wspierał zakon, a w testamencie zapisał mu kilka tysięcy złotych na odnowienie szat i ubiorów w kościele miechowskim.

W lutym $1621 \mathrm{r}$. synod diecezjalny krakowski poddał zakon pod jurysdykcję biskupa krakowskiego, mimo że zakon posiadał immunitet papieża Urbana IV z 4 listopada $1262 \mathrm{roku}^{55}$. Dzięki staraniom Macieja Łubieńskiego na synodzie prowincjalnym w Piotrkowie w kwietniu $1621 \mathrm{r}$. została uchylona uchwała synodu diecezjalnego krakowskiego.

Po rezygnacji prepozyta komendatoryjnego Konstantego Felicjana Szaniawskiego (1700-1706) kapituła generalna, wykorzystując dogodną sytuację, wybrała 12 stycznia 1707 r. prepozytem Stanisława Stępkowskiego (1660-1742), prepozyta chorzowsko-bytomskiego. Stępkowski został zarekomendowany papieżowi 24 stycznia 1707 r. przez legata papieskiego Królestwa Polskiego przebywającego w Opawie na Śląsku. Niestety elekt nie został zatwierdzony przez króla, a zakonnikom narzucono Teodora Wolffa von Ludinghausa (1710-1712), biskupa inflandzkiego. Według uchwał kapituły generalnej z lat 1718 i 1719, zatwierdzonych przez papieża Klemensa XI, prepozytom komendatoryjnym nie przysługiwała jurysdykcja w klasztorze miechowskim i jego placówkach. Zgromadzenie miało prawo wybierać przełożonego z własnego grona, zaś komendatariusze mieli tylko tytuł i beneficjum z łaski królewskiej, z którego zobowiązani byli przekazywać czwartą część dochodów na konserwację i naprawę kościoła i zabudowań klasztornych. Komendatariusze (Krzysztof Jan Szembek [1712-1724], Antoni Rozdrażewski [1725-1732] nie wywiązywali się z tych zobowiązań, dlatego wciąż trwał konflikt między zakonnikami a komendatariuszami i królem. Na nic zdały się interwencje zakonników, na czele których stał Stanisław Stępkowski i Jakub P. Radliński (1744-1762), w Stolicy Apostolskiej w Kongregacji Partykularnej do spraw polskich. 11 lutego 1726 r. król nakazał wstrzymać się z wyborem prepozyta klasztornego, którym ponownie miał zostać Stanisław Stępkowski, i podziałem dóbr pod rygorem sekwestru i innych kar. 22 marca 1726 r. Benedykt XIII zatwierdził dekret mówiący, że komendatariusze nie mają władzy w klasztorze i podział dochodów, a projekt podziału dóbr przyjęty przez kapitułę generalną został zatwierdzony przez króla w 1727 r., ostatecznie porozumienie potwierdzono w konkordacie z 1737 r. Po śmierci Rozdrażewskiego bożogrobcy znowu rozpo-

\footnotetext{
${ }^{54}$ AGAD, nr 2808.

${ }^{55} \mathrm{BP}, \mathrm{t} .1, \mathrm{nr} 731$.
} 
częli walkę z instytucją komendy. Czynny udział w konflikcie między zakonnikami a komendatariuszami brał udział Stanisław Stępkowski, dążąc do uniezależnienia się klasztoru miechowskiego od wpływów komendatriuszy, a nawet zniesienia komendy, dążył on do uzyskiwania odpowiednich funduszy na funkcjonowanie kościoła i klasztoru miechowskiego.

W 1723 r. na kapitule generalnej pod wpływem Stępkowskiego zaostrzono dyscyplinę zakonną i wprowadzono wielki nacisk na właściwą formację, utrzymanie studium generalnego i coroczne rekolekcje. Pierwszym prepozytem klasztornym „praepositus generalis claustralis infulatus” został 20 października 1732 r. kustosz i administrator generalny zakonu Stanisław Stępkowski, zatwierdzony 18 sierpnia 1734 r. przez Klemensa XII. Zachował on prawo używania insygniów biskupich (infuły, pastorału, pierścienia) i podlegał zatwierdzeniu wyłącznie przez papieża. Formalne wprowadzenie siedemdziesięciopięcioletniego Stępkowskiego nastąpiło 16 lutego $1735 \mathrm{roku}^{56}$. Jednak w dalszym ciągu administratorami komendy miechowskiej byli biskupi biedniejszych diecezji.

Niestety komendatariusze, będący równocześnie biskupami w diecezjach, nie interesowali się zakonem, a tylko dochodami z przysługujących im beneficjów. W ich posiadaniu były dwa miasta i 28 wsi. Po pożarze w 1745 r., który zniszczył miasto Miechów wraz z kościołem i klasztorem, konwent zażądał od komendatariusza biskupa kamienieckiego Mikołaja Dembowskiego (1743-1757) przekazania części dochodów z komendy na odbudowę (administratorzy komendy byli zobowiązani oddawać $1 / 3$ część dochodów na potrzeby kościoła). Ten jednak nie zamierzał tego zrobić, dlatego też sprawa oparła się o Rzym. Orzeczeniem z 6 lipca 1756 r. dokonano rewizji i nowego podziału dóbr komendy, które zatwierdził nuncjusz papieski 2 października 1756 r. i Kongregacja Partykularna w Rzymie 14 marca 1757 roku $^{57}$. Następca Dembowskiego, biskup kijowski Kajetan Sołtyk (1758-1759), chciał ten podział unieważnić, aby odebrać zakonowi Miechów z przynależnościami, lecz po otrzymaniu biskupstwa krakowskiego zrzekł się komendy, a pomysłu owego zaniechał.

Z inicjatywy Hugona Kołłątaja (1750-1812) powstała koncepcja kasaty zakonu bożogrobców i przekazania jego majątku Akademii Krakowskiej. W czerwcu 1777 r. król Stanisław August Poniatowski z Radą Nieustającą i biskupem płockim Michałem Poniatowskim koadiutorem krakowskim i kanclerzem uniwersytetu wysłali do Stolicy Apostolskiej memoriał wykazujący bezużyteczność zakonu, wychwalając zaś zalety Akademii i konieczność kształcenia młodzieży. Jednak kongregacja kardynałów odmówiła kasaty. Jednak 23 sierpnia 1784 r. król dekretem inkorporacyjnym przekazał dobra komendy miechowskiej na rzecz uniwersytetu $^{58}$. Niestety Komisja Edukacji Narodowej nie przekazała ich uczelni, lecz były one źródłem dochodu osób prywatnych, a Akademia Krakowska nie czerpała z nich żadnych korzyści.

${ }^{56}$ R. Skrzyniarz, Stempkowski Stanisław, PSB, t. 43 (2004-2005) s. 396-397; tenże, Stępkowski Stanistaw, EK, t. 18, Lublin 2013, kol. 952-953.

${ }^{57}$ Archiwum Parafialne w Miechowie, Aprobatio divisionis bonorum praepositurae Miechowiensis; Kronika klasztorna 1749, 1757.

${ }^{58}$ Archiwum Parafialne w Miechowie, Acta conventus generalia, s. 149 i nn.; Pęckowski, Miechów, s. 338. 
Prepozyci komendatoryjni, z których większość stanowili biskupi, przyczynili się do upadku moralnego zakonu. Ciągłe spory między biskupami i królem a klasztorem o korzyści materialne $\mathrm{z}$ dóbr zakonnych, zły przykład dawany przez prepozytów komendatoryjnych, brak autorytetu i silnej ręki, spowodowały w zakonie rozprzężenie, a zarazem rozluźnienie karności, ciągłe łamanie reguły zakonnej, gnuśność, bezczynność, pijaństwo i niemoralność. Próby reform podejmowane przez prepozytów klasztornych nie były w stanie powstrzymać upadku moralnego w zakonie, gdyż zły przykład szedł z góry.

W 1817 r. biskupi polscy zwrócili się do rządu o wyjednanie u Stolicy Apostolskiej zniesienia niektórych bogatych klasztorów, w celu zapewnienia funduszy na uposażenie diecezji, kapituł i seminariów duchownych oraz na utworzenie biskupstwa w Janowie Podlaskim. Papież Pius VII 30 czerwca 1818 r. zezwolił na kasatę klasztorów, a arcybiskup warszawski Franciszek Skarbek-Malczewski (1754-1819) 17 kwietnia 1819 r., na dzień przed śmiercią, podpisał kasatę wyznaczonych 29 klasztorów męskich i 6 żeńskich, w tym klasztoru miechowskiego ${ }^{59}$. Tym samym przyczynił się do kasaty całego zakonu bożogrobców, który z powodu braku metropolii w Miechowie stracił moc prawa patronatu nad obsługiwanymi przez siebie kościołami oraz możliwości kształcenia nowych kadr. W historii zakonu bożogrobców biskupi byli darczyńcami, dobroczyńcami, obrońcami, ale też przyczynili się jego do upadku moralnego i gospodarczego, a w ostatecznym rozrachunku do upadku i zaniku jego wielowiekowej tradycji wychowania i edukacji oraz rozwoju kultury w społeczeństwie polskim.

${ }^{99}$ Pęckowski, Miechów, s. 346-348; P.P. Gach, Kasata zakonu bożogrobców na ziemiach polskich w XIX wieku, w: Bożogrobcy w Polsce, praca zbiorowa, Miechów-Warszawa 1999, s. 113127. 
BISHOPS AND ORDER OF THE HOLY SEPULCHRE ON POLISH LANDS IN YEARS OF 1163-1819. OVERVIEW

\begin{abstract}
Summary
In the first phase of bringing the Order of the Holy Sepulchre down to Poland in 1163, bishops of dioceses were founders and donors of the Order (Cracow Bishop Gedko, Plock Bishop Lapus) and acknowledged the foundations as the heritage left by their predecessors. In 15th Century they were Gniezno Archbishop Mikołaj Trąba and Kiev Bishop Michał Treska. Since 14th Century the assets belonging to the Order of Holy Sepulchre had been titbits for bishops, especially for the poorer dioceses but also for Cracow bishops (Piotr Gamrat). Conflicts arose from recruitment procedures conducted in the Order where bishops employed diocesan priests. Since 1567 or the establishment of the commendation, commendatory provosts, where bishops had been in majority, had contributed to moral decline of the Order. The positive conduct of Andrzej Batory and Maciej Łubieński exclusively stood out. Permanent disputes among bishops, the king, and the monastery for material benefits derivable from the Order's assets, bad examples set by commendatory provosts, the lack of authority and authoritarianism resulted in the laxity of morals in the Order and concurrently accounted for the relaxation of discipline, violation of the rules and laws made by the Order, sloth, idleness, drunkenness and immorality. In 18th Century the attempts to reform the Order, made by the provosts, were insufficient and unsuccessful to control the status quo in the Order because of the bad example that came from the top.
\end{abstract}

